\title{
Protection and ownership of research results
}

\author{
Justyna Ożegalska-Trybalska
}

Department of Intellectual Property Law, Jagiellonian University, Cracow, Poland

Introduction. This article aims to present the rules concerning the protection and ownership of the results of scientific research and development works and related know-how, including those jointly generated in multicentre research projects. Material and methods. The analysis focuses on the identification of types of medical research results and the possibility of protecting them under intellectual property law, including copyright, patent and unfair competition law. It also considers regulations providing provisions on the ownership and commercialisation of R\&D results acquired under research programmes, projects and sponsored research, including clinical trials.

Results. The lack of protection of research results as such by intellectual property rights, the different nature of those results, as well as potential conflicts of interests that arise from the exploitation of data which has both scientific and market value, may in practice cause problems in regard to who is entitled to them and what are the rules for their use and publication. Situations of conflict may arise at the interface between the interests of the different actors involved in conducting and financing research (researchers, research centres, sponsors).

Conclusion. Effective management of research and development results requires identification of the appropriate regime (statutory, project or contractual) under which they were obtained and are going to be exploited. Although the rules in force for the acquisition of rights can only be modified contractually to a certain extent, it is strongly recommended to supplement them with detailed contractual provisions specifying the rules for the co-ownership of results, the rights and obligations of the entities involved in the research, as well as ensuring confidentiality and restrictions on their disclosure with and/or without the consent of co-authors and sponsors financing research.

Key words: protection of research results, ownership of research results, joint research, clinical trials, confidentiality of research results.

\section{Introduction}

Research results lack uniform rules on their protection, ownership, and exploitation. There are additional aspects to this problem with regard to medical research results, which include the need to transfer them into practice, financing costly research, meeting administrative requirements for the authorization of medical products, ensuring ethical standards and protecting the privacy of individuals in clinical trials. Thus, medical research results have an important characteristic: they are not purely scientific, but most often utilitarian and commercial, and in terms of their ownership and accessibility, the interests of individual scientists, research sponsors and members of society should be considered, who claim the right of freedom of research and the right to access to the latest treatments for the protection of their health.

\section{Material and methods}

The starting point for establishing rules for the protection and acquisition of rights to research results is to clarify this term, which in the field of medicine may relate to scientific discoveries, concepts and hypotheses (in particular those related to the use of new substances and therapies), the results of clinical

\section{How to cite:}

Ożegalska-Trybalska J. Protection and ownership of research results. NOWOTWORY J Oncol 2020; 70: 163-166. 
research and assessments, tests, medical experiments, biomedical, epidemiological, behavioral research, results obtained through screening programmes, diagnostic tests, treatment trials, as well as the results of medical technology research and factors influencing health. A separate category is made up of results used in specific products and technologies applied in medicine. Such a heterogeneous group determines the problems in regard to the legal grounds for determining the ownership of results [1]. This applies especially to the results of studies conducted jointly by many research centres (domestic and foreign), and results obtained in sponsored clinical trials that are subject to specific statutory regulations.

Although the intuitive regime protecting the results of research and development activity is intellectual property law - contrary to common belief - this does not provide tools for the protection of research results as such, even though they have undeniable scientific, commercial and application value. The results of research and scientific activities, including the results of clinical trials as numerical data, parameters and statistics, are not subject to copyright or patent protection, and thus the regulations do not provide for the acquisition of exclusive intellectual property rights to them [2]. A legal monopoly on the results of medical research is not available in order to not limit the access of society to such results and to allow the execution of a constitutionally guaranteed principle of freedom of research. Even though entities conducting research do not acquire property rights to the results, they retain a kind of "authorship" of the results under the protection of personal rights which ensures affiliation with research results.

The absence of exclusive rights to the results of research does not preclude their actual or contractual monopolization as data possessing certain scientific or market value. Exclusive intellectual property rights may be acquired to works in which research results have been described, discussed and verified (scientific articles, conference posters presenting results, reports, studies, databases containing results). Inventions which use these results can be also patented. According to the general ownership regimes of IP rights, an author's economic rights to a work or the right to obtain a patent for an invention are vested in the author or co-authors on the principle of the commonality of rights (Article 8 and 9 of the Copyright Act and Article 11 paragraph 1 and 2 of the Industrial Property Act). If such creations have been created by an employee in the performance of his/her duties, the rights are acquired by the employer which employs the scientist (researcher), unless the employment contract provides for other rules in this respect (Article 12 of the Copyright Act and Article 11 paragraph 3 of the Industrial Property Act). Depending on the contractual arrangements for the involvement of an individual participant in the research, in the case of multicentre research, rights may be acquired by the centres employing them or those individuals (if they are researching on a basis other than a contract of employment or outside of their employment obligations). The exception to this rule concerns employee copyrighted scientific works created in universities and research centres, to which the author's economic rights are vested in the employees and not in the research unit. The latter has only a legally guaranteed right to the first publication of the scientific work (Article 14 of the Copyright Act). Due to the competition of scientific centres regarding the affiliation of publications containing the most current or pioneering research results, collisions in the exercise of priority rights concerning co-publications involving authors from different centres are possible.

\section{Results}

Despite the exclusion of research results from intellectual property law protection, it is possible to acquire actual exclusivity of results which have market applicability and value by safeguarding their confidentiality. The legal basis for the protection of confidential research results is the Act on Combating Unfair Competition of 16 April 1993 [3]. According to Article 11 of this regulation that has recently been harmonized with EU standards, it is possible to protect such results as a so-called company secret (confidential know-how) from disclosure, use or unauthorized acquisition, provided that they are not generally known to persons normally dealing with such results or are not easily accessible to such persons and the entity entitled to the results has taken steps, with due diligence, to keep them confidential. The requirement to take steps to keep results confidential should be implemented in practice, in particular by signing clauses or confidentiality agreements with employees, members of research teams, researchers involved in sponsored trials, clinical trial or health technology assessments. The right to use or dispose of results whose market value is due to their confidentiality may belong to the research team or centres where the research is conducted or the research sponsor. Disclosure or obtaining such results shall constitute an act of unfair competition, if it occurs without the consent of the rightsholder and results from unauthorized access, misappropriation, or the copying of documents, objects, materials, substances or electronic files containing the results. Obtaining results identical to somebody else's confidential know-how is permissible when it has occurred as a result of independent discovery, production, observation, research, or testing, or to protect a legitimate public interest (e.g. to avoid the use of falsified or unreliable results of medical research, for the functioning of the health care system, obtaining permission to market a medicine, etc.).

In addition to the general statutory regulations, the provisions providing for who is entitled to research results, what the rules are for their use, publication and commercialisation may result from separate statutory or contractual regulations, including agreements with clinical trial sponsors or research funding schemes for national and international research projects.

In the coming years, the most important research funding mechanism for Polish researchers in the EU will be Horizon 
Europe 2021-2027, which also provides, under priority research areas, funding for research in the area of health. Although the EU regulation on participation in research projects implemented under the program is not yet approved, it will set out detailed rules, binding for participants, on the management of research results obtained from projects financed from this source in regard to the ownership of research results, obligations related to their protection and dissemination and the granting of so-called access rights to them [4].

At the national level, specific provisions on the management of and know-how related to research and development results are laid down in the Act on Higher Education and Science of 20 July 2018 and the Act on Research Institutes of 30 April 2010 [5]. Issues concerning the ownership of the results of research projects financed from the resources of the National Centre for Science (NCN) and the National Centre for Research and Development (NCBiR) are regulated by the respective acts [6] and may be subject to specific rules for the implementation of strategic programs (such as, for example, NCBiR's program "Prevention and treatment of civilization diseases" - STRATEGME). As far as intellectual property rights are concerned, they respect the general principles of acquiring rights indicated earlier, by mentioning that, in the case of results obtained in NCN and NCBiR projects, they belong to the entity to which the funds have been allocated unless an agreement between the Centre and the entity receiving the funds or the decision to allocate funds provides otherwise [6].

Independent standards apply to the results of clinical trials, both commercial and non-commercial, which, at the national level, are provided for in the Pharmaceutical Law of 6 September 2001 [7] and the implementing Act on Good Clinical Practice [8]. It follows from these regulations that the ownership of clinical trial results is vested in the sponsor, who may transfer the ownership of all or part of the data or the right to dispose of all or part of the data related to the clinical trial to another entity by means of a written agreement. The limitations in use and transfer apply to results generated in non-commercial clinical trials, i.e. where the owner of the results generated in the course of the clinical trial is a university or other scientific institution, investigator or organization of researchers. The results of non-commercial clinical trials are intended to serve cognitive, scientific, non-commercial purposes and may be disseminated, for example, through scientific publications. However, they may not be used for marketing purposes or to make changes to an existing marketing authorization required for a medicinal product to be put on the market.

\section{Conclusion}

On the one hand, research results as such do not constitute an independent object of protection, on the other hand, they are an essential element required for the development and marketing of medical products and services. This may cause a conflict of interest between the free use of research results and making them available to the public (in particular by publishing them as soon as possible in scientific journals or as part of conference speeches) and maintaining their confidentiality (novelty), necessary for market monopolization based on know-how or patent protection. Potential areas of conflict are situations where research results are obtained through joint research activities, where the problem of priority of their publication, joint commercialisation or use in further, independent research may arise. This requires the taking adoption of legal measures and contractual tools [9].

To avoid disputes concerning the ownership of results and their use in scientific and commercial activities, it is recommended to conclude agreements on joint research work or to adapt model agreements relevant for a given research activity (such as, e.g. NCN projects, multicentre research, projects founded from EU programs). These should specify: the rules for the allocation of intellectual property rights generated by the research project or access rights to the results generated by joint research, as well as the rights and obligations of research stakeholders in the use of the results, including their publication and commercialization. The contracts should require, in particular, that participants keep research logs documenting the contributions of individuals in their research team.

Provisions concerning the confidentiality of research results, the prohibition of their disclosure, the rules of notification of planned publication of results and the transfer of intellectual property rights should be specified in particular in contracts for sponsored studies, including contracts for conducting clinical trials [10]. It should be borne in mind that the disclosure of the results of studies which have scientific value and validity, e.g. in an individual scientific publication or a research centre, may deprive such results of their application and market value, including preventing the funding entity or sponsor from obtaining exclusivity under the intellectual property rights system for products and technologies which use such results.

Conflict of interest: none declared

\author{
Justyna Ożegalska-Trybalska \\ Jagiellonian University \\ Intellectual Property Law Chair \\ ul. Józefa 19 \\ 31-056 Kraków, Poland \\ e-mail:j.ozegalska-trybalska@uj.edu.pl
}

Received and accepted: 22 Jun 2020

\section{References}

1. Kasprzycki D. Ochrona wyników badań naukowych. In: Adamczak A ed. Ochrona, wyczerpanie i korzystanie z praw własności intelektualnej, z uwzględnieniem prawa i orzecznictwa unijnego oraz praktyki EPO, Wynalazczość i ochrona własności intelektualnej. Nr 37. 2013: 19.

2. Wyraźne wyłączenie idei, odkryć, metod, danych statystycznych zawierają zarówno regulacje międzynarodowe, jak i krajowe przepisy ustawy o prawie autorskim i prawach pokrewnych z 4 lutego 1994 r., t.j. Dz. U. z 2019 r. poz. 1231, z 2020 r. poz. 288., a w zakresie twórczości 
wynalazczej - ustawy Prawo własności przemysłowej z 30 czerwca 2000 r. t.j. Dz. U. z 2019 r., poz. 1010, 1649.

3. Dz. U. z 2019 r. poz. $1010,1649$.

4. Wniosek-Rozporządzenie Rady ustanawiające program badawczo-szkoleniowy Europejskiej Wspólnoty Energii Atomowej na lata 2021-

2025 uzupełniający program ramowy w zakresie badań naukowych i innowacji „Horyzont Europa”, COM/2018/437 final - 2018/0226 (NLE).

5. Art. 153-158 ustawy z dnia 20 lipca 2018 r. Prawo o szkolnictwie wyższym i nauce, t.j. Dz. U. z 2020 r. poz. 85, 374, 695, 875 oraz ustawa z dnia 30 kwietnia 2010 r. o instytutach badawczych, t.j.Dz. U. z 2019 r. poz. 1350,2227, z 2020 r. poz. 284.
6. Ustawa z dnia 30 kwietnia 2010 r. o Narodowym Centrum Nauki, t.j. Dz. U. z 2019 r. poz. 1384 oraz ustawa z dnia 30 kwietnia 2010 r. o Narodowym Centrum Badań i Rozwoju, t.j. Dz. U. z 2019 r. poz. 1770, 2020 z 2020 r. poz. 284, 695.

7. Dz. U. z 2008 r. Nr 45, poz. 271, z późn. zm.

8. Rozporządzeniu Ministra Zdrowia z dnia 2 maja 2012 r., Dz. U. z 2012 r. poz. 489.

9. Bakalarz T. Ochrona wyników badań naukowych. Przegląd Prawa Gospodarczego. 2011(6): 35.

10. Swatyniec $Ł$. Umowy w badaniach klinicznych, komentarz praktyczny. LEX. 